\title{
Impact of physical exercise on quality of life of older adults with depression or Alzheimer's disease: a systematic review
}

\author{
O impacto do exercício físico na qualidade de vida de idosos com depressão \\ ou com doença de Alzheimer: uma revisão sistemática
}

\author{
Bianca Boscarino Tavares, ${ }^{1}$ Helena Moraes, ${ }^{2}$ Andrea Camaz Deslandes, ${ }^{2}$ Jerson Laks ${ }^{3}$
}

\begin{abstract}
Introduction: Physical exercise has been associated with improvement of quality of live (QoL), but its effect among the elderly with depression and Alzheimer's disease (AD) is still unclear. This systematic review evaluated randomized and controlled studies about the effect of physical exercise on QoL of older individuals with a clinical diagnosis of depression and AD. Methods: We searched PubMed, ISI, SciELO and Scopus from December 2011 to June 2013 using the following keywords: physical exercise, quality of life, elderly, depression, Alzheimer's disease. Only six studies met inclusion criteria: two examined patients with $A D$ and four, patients with depression.

Results: The studies used different methods to prescribe exercise and evaluate QoL, but all had high quality methods. Findings of most studies with individuals with depression suggested that exercise training improved QoL, but studies with patients with $A D$ had divergent results.

Conclusions: Although different methods were used, results suggested that physical exercise is an effective nonpharmacological intervention to improve the QoL of elderly individuals with depression and AD. Future studies should investigate the effect of other factors, such as the use of specific scales for the elderly, controlled exercise prescriptions and type of control groups.
\end{abstract}

Keywords: Quality of life, elderly, depression, Alzheimer's disease.

\begin{abstract}
Resumo
Introdução: O exercício físico parece estar relacionado à melhora na qualidade de vida (QdV), mas seus efeitos em populações de indivíduos idosos com depressão ou Doença de Alzheimer (DA) ainda não foram estabelecidos. Esta revisão sistemática avaliou estudos controlados randomizados sobre os efeitos do exercício físico sobre a QdV em idosos com diagnóstico clínico de depressão e DA.
\end{abstract}

Métodos: Foi feita uma busca nas bases de dados PubMed, ISI, SciELO e Scopus de dezembro de 2011 a junho de 2013 usando os seguintes descritores: exercício físico, qualidade de vida, idosos, depressão, doença de Alzheimer. Apenas seis estudos satisfizeram os critérios de inclusão: Dois com pacientes com DA e quatro com pacientes com depressão.

Resultados: Os estudos adotaram metodologias diferentes de prescrição de exercícios e avaliação de QdV, mas todos preencheram os requisitos de alta qualidade metodológica. Os resultados da maioria dos estudos com idosos com depressão sugerem que a QdV melhora com o treinamento físico, mas os estudos com pacientes com DA tiveram resultados divergentes. Conclusões: Apesar de os estudos usarem metodologias diferentes, seus resultados sugerem que os exercícios físicos são uma intervenção não-farmacológica efetiva para melhorar a QdV entre idosos com depressão e DA. Estudos futuros devem investigar os efeitos de outros fatores, tais como o uso de questionários específicos para idosos, a prescrição controlada de exercícios, e o tipo de grupo controle.

Descritores: qualidade de vida, idosos, depressão, doença de Alzheimer.

\footnotetext{
${ }^{1}$ Exercise Neuroscience Laboratory, Universidade Federal do Rio de Janeiro (UFRJ), Rio de Janeiro, RJ, Brazil. ${ }^{2}$ Exercise Neuroscience Laboratory, UFRJ, Rio de Janeiro, RJ, Brazil. Center for Alzheimer's Disease and Related Disorders, Institute of Psychiatry, UFRJ, Rio de Janeiro, RJ, Brazil. ${ }^{3}$ Center for Alzheimer's Disease and Related Disorders, Institute of Psychiatry, UFRJ, Rio de Janeiro, RJ, Brazil. Researcher 2, Conselho Nacional de Desenvolvimento Científico e Tecnológico (CNPq), Brazil. Centro de Estudos e Pesquisa do Envelhecimento - Instituto Vital Brasil (CEPE/IVB), Rio de Janeiro, RJ, Brazil.

Financial support: none.

Submitted Dec 16 2013, accepted for publication Jun 12 2014. No conflicts of interest declared concerning the publication of this article.

Suggested citation: Tavares BB, Moraes H, Deslandes AC, Laks J. Impact of physical exercise on quality of life of older adults with depression or Alzheimer's disease: a systematic review. Trends Psychiatry Psychother. 2014;36(3):134-139. http://dx.doi.org/10.1590/2237-6089-2013-0064
} 


\section{Introduction}

Epidemiological data have shown a significant increase of the aging population around the world, especially in developing countries. ${ }^{1}$ It is expected that within the next fifty years there will be 58 million older individuals, accounting for $23.6 \%$ of the total population. ${ }^{2}$ According to the Brazilian Public Health System, public spending with hospitalizations of older individuals was US\$ 659 million in 1996. ${ }^{3}$ Chronic diseases associated with aging, such as depression and Alzheimer's disease $(A D)$, have already become a growing demand in public health services. ${ }^{4}$ However, epidemiological studies about dementia and depression in elderly populations should take into consideration the limits between depression and depressive symptoms, as well as the cognitive decline of healthy aging. ${ }^{5}$

A common feature of depression and $A D$ is low quality of life (QoL).4,6 According to the World Health Organization, QoL is defined as an individual's perception of their position in life, in the context of the culture and value systems in which they live, and in relation to their goals, expectations, standards and concerns. ${ }^{7}$ QoL evaluation is extremely important for public health, and some economic indexes have been developed for that purpose. Among them, the quality-adjusted life years (QALY) index estimates quality years earned, whereas the disability-adjusted life years (DALY) index calculates years lost due to disability. ${ }^{8,9} \mathrm{QoL}$, a ubiquitous concept, is associated with social, psychological, and functional factors. Therefore, an increased prevalence of depression and $A D$ among the elderly may lead to lower QoL. Especially in AD, cognitive and motor changes may increase dependency on others for the performance of activities of daily living, which may limit QoL. ${ }^{10,11}$ Moreover, impaired awareness of disease may affect the subjective evaluation of QoL. ${ }^{12}$ However, the association of QoL with depression and AD remains unclear. ${ }^{13}$

Some studies have pointed out that physical exercise is a low-cost intervention to improve QoL among older populations. ${ }^{14-16}$ In addition to cardiovascular and musculoskeletal benefits, exercise promotes an increase in cognitive performance, self-effectiveness and motor control, which leads to improved functional capacity and QoL. ${ }^{14,16,17}$ However, current evidence applies to healthy individuals ${ }^{18,19}$ and individuals with depressive symptoms. ${ }^{15,20}$ Few studies have included older individuals with a clinical diagnosis of major depression and AD. ${ }^{21-26}$ Although data about this association are scarce, previous reviews concluded that the differences in exercise type and QoL evaluations might have affected comparisons between studies. ${ }^{27,28}$ Moreover, some of those reviews included adults in general and analyzed other variables, in addition to QoL.
The effect of physical exercise on QoL should be assessed in groups of older patients with depression and AD. This study reviewed randomized controlled trials that included patients with a clinical diagnosis of depression or AD and analyzed type of exercise and QoL measurement.

\section{Methods}

This systematic review, conducted from December 2011 to June 2013, followed the Preferred Reporting Items for Systematic Reviews and Meta-Analyses (PRISMA) statement.

\section{Criteria for eligibility}

We reviewed randomized controlled trials that investigated the effect of exercise on QoL using different exercise types and intensities, written in English or Portuguese. Studies were included only if they used specific scales to assess QoL and included individuals older than 60 years who had a clinical diagnosis of depression or AD.

\section{Information sources}

We searched PubMed, ISI, SciELO and Scopus using the following keywords: (physical exercise) AND (elderly) AND (quality of life) AND (depression) AND (Alzheimer disease). Additionally, the references of published studies were reviewed. Full-text versions of all potentially relevant articles were downloaded from the electronic databases or requested directly from the authors.

\section{Search}

The following criteria and limits were used to search PubMed for studies about the effect of exercise on QOL in elderly patients with depression: (("exercise"[MeSH Terms] OR "exercise"[All Fields]) OR ("physical"[All Fields] AND "exercise"[All Fields] OR "physical exercise"[All Fields]) AND ("quality of life"[MeSH Terms]) OR ("quality"[All Fields] AND "life"[All Fields]) OR ("quality of life"[All Fields]) AND ("aged"[MeSH Terms] OR "aged"[All Fields] OR "elderly"[All Fields]) AND ("depressive disorder"[MeSH Terms]) OR ("depressive"[All Fields] AND "disorder"[All Fields]) OR "depressive disorder"[All Fields] OR "depression"[All Fields] OR "depression"[MeSH Terms])) AND ("humans"[MeSH Terms] AND Randomized Controlled Trial[ptyp] AND English[lang] AND "aged"[MeSH Terms]). The same criteria and limits were used for 
studies that included patients with $A D$, but the terms used were: ("alzheimer" [All Fields] AND "disease" [All Fields]) OR "alzheimer disease" [All Fields])). In ISI, SciELO and Scopus, depression and Alzheimer's disease were included in specific searches with the following keywords: physical exercise AND quality of life AND elderly.

\section{Data collection}

After a first double screening of titles and abstracts, the studies were selected for full-text reading by two reviewers. In case of disagreement between them, the results were discussed with a third reviewer.

\section{Selection of studies}

We excluded studies that used physical exercise together with other interventions, as well as studies that did not include any clinical diagnosis. We also used the PEDro scale, ${ }^{29}$ an 11 -criterion scale that assess methods and statistical quality of randomized controlled trial according to scores that range from zero to 10 .

\section{Risk of bias}

Bias measurement was based on the type of exercise (supervised and non-supervised) and control group (with or without social contact), because these two factors may affect depressive symptoms, mood, and QoL. Moreover, randomization and blinding were evaluated in all studies.

\section{Results}

Our literature search yielded 375 studies about elderly patients with depression and 47 about patients with $A D$. One more study was found in the references and added to this review. Figures 1 and 2 illustrate the steps taken to select the studies.

Two studies with individuals with AD, selected according to the inclusion criteria, had contradictory results of QoL scales. In one of them, there was a significant improvement of QoL measured using the Medical Outcomes Study 36-Item Short-Form Health Survey $\left(\mathrm{SF}-36^{\circledR}\right),{ }^{26}$ a multidimensional questionnaire that covers eight domains: physical functioning, role physical, mental health, role-emotional, social functioning, vitality, pain and general health. ${ }^{30}$ However, only results in the physical functioning item were significant. In contrast, Steinberg et al. ${ }^{25}$ found a non-significant improvement of QoL measured using the Alzheimer's Disease-Related Quality of Life (ADQRL) scale. The control group in one study was a home-safety assessment group ${ }^{25}$ and in the other, a group of patients that received routine medical care and no intervention. ${ }^{26}$

The evaluation of depression, also using the SF$36^{\circledR}$, revealed that all studies had significant results. There was significant improvement in all domains, except in general health. ${ }^{21-24}$ Exercises were different, especially in type, intensity, and duration of the intervention. Control groups were also different: three studies used social contact and health education ${ }^{21-23}$ and one, no intervention. ${ }^{24}$

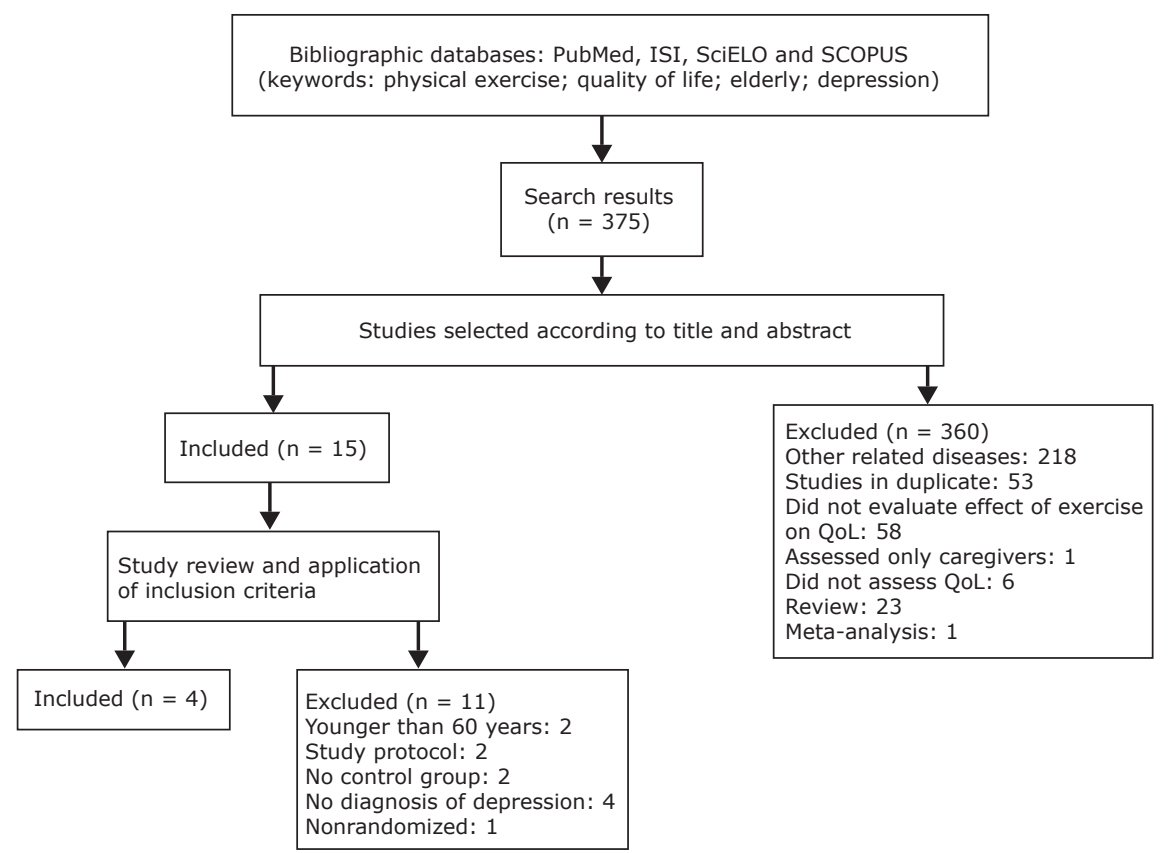

Figure 1 - Flowchart of search and selection of studies that included older individuals with depression. 


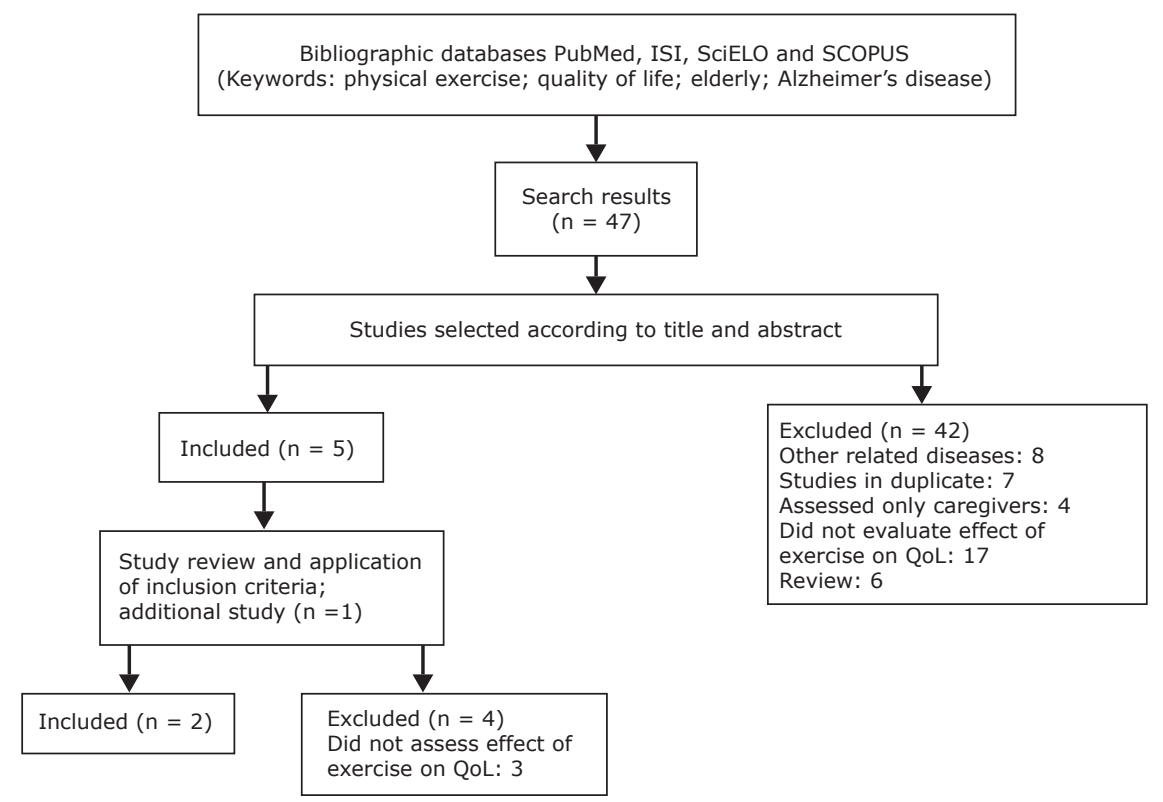

Figure 2 - Flowchart illustrating search and selection of studies that included older individuals with Alzheimer's disease.

Only two studies were blinded to group allocations and follow-up evaluations. ${ }^{18,24}$ The assessment of study quality using the PEDro scale showed that all six selected studies had scores greater than or equal to six and were classified as high-quality studies. Table 1 summarizes the characteristics and results of these studies.

\section{Discussion}

This study reviewed studies that investigated the effect of physical exercise on QoL in older individuals with depression or AD. Although some studies found significant improvement of QoL, findings were different for specific aspects of QoL and type of exercise.

Studies have used different exercise types, such as strength training, ${ }^{23,24}$ tai chi chih, ${ }^{21}$ and combined exercise (strength, aerobic, balance, and flexibility). ${ }^{22,25,26}$ Results on QoL were positive, especially in studies that included elderly individuals with depression. However, these studies used different exercise types and intensities, and it is, therefore, unclear what effect these variables have on QoL. The practice of tai chi chih resulted in physical improvement only, whereas strength training alone and together with other exercises promoted significant improvement in some physical and mental aspects assessed using the SF-36 ${ }^{\circledR} .{ }^{22-24}$ According to Singh et al., ${ }^{23,24}$ high intensity exercises may improve QoL. Different exercise types and intensity, together with psychological and physical symptoms of depression, may also affect the perception of QoL, because these evaluations are subjective. ${ }^{31}$

Only two studies about AD met the inclusion criteria for this review. In one of them, there was significant improvement of the physical aspect measured using the SF- $36^{\circledR}{ }^{\circledR 2}$ However, the type of exercise was not described, and the scale used was not specifically designed for individuals with $A D$. In contrast, the results of another study using a QoL scale specific for individuals with AD, the Alzheimer's Disease-Related Quality of Life (ADQRL) scale, were not significant. ${ }^{25}$ Some factors were identified as biases, such as the difference in QoL scores between groups at baseline and higher scores in the depression scale after the intervention. Despite the association between depression and $A D$, mean depression score was not above the cut-off point. Moreover, although these studies investigated the same type of exercise, they used different QoL scales, which may affect their comparison.

The most frequent scale in the studies included in this review was the $\mathrm{SF}-36^{\circledR}$, a frequently used instrument validated for the general population. ${ }^{30}$ However, QoL concepts may be different for young people, adults, and the elderly. The elderly usually rate their QoL according to material and social factors and their independence in activities of daily living, ${ }^{32}$ whereas younger individuals assign greater importance to work than to health. ${ }^{33}$ Therefore, to improve result reliability, future studies should use scales specifically designed for older populations. 
Exercise, depression and Alzheimer's disease - Tavares et al.

Table 1 - Characteristics of studies assessing quality of life in elderly with depression and Alzheimer's disease

\begin{tabular}{|c|c|c|c|c|c|c|}
\hline Studies & $\begin{array}{l}\text { PEDro } \\
\text { scale }\end{array}$ & Sample & Design & Exercise & $\begin{array}{c}\text { QoL } \\
\text { measure }\end{array}$ & Results \\
\hline Lavretsky et al. ${ }^{21}$ & 8 & $\begin{array}{c}E: 69.1 \pm 7.0 y \\
(n=33) C: 72.0 \pm 7.4 \\
(n=35) M D\end{array}$ & $\begin{array}{l}\text { Longitudinal } \\
\text { (10 weeks) } \\
\text { supervised }\end{array}$ & $\begin{array}{l}\text { Tai Chi Chin } \\
2 \text { hours/week }\end{array}$ & SF-36 & $\begin{array}{l}\text { E > C: physical } \\
\text { function }\end{array}$ \\
\hline Kerse et al. ${ }^{22}$ & 8 & $\begin{array}{c}81.1 \pm 4.4 \mathrm{y} \\
\mathrm{E}(\mathrm{n}=94) \\
\mathrm{C}(\mathrm{n}=87) \mathrm{MD} \text { or depressive } \\
\text { symptoms }\end{array}$ & $\begin{array}{l}\text { Longitudinal } \\
\text { (12 months) } \\
\text { unsupervised }\end{array}$ & $\begin{array}{l}\text { Strength, balance } \\
\text { and aerobic } \\
3 \text { days/week }\end{array}$ & SF-36 & $\begin{array}{l}\Uparrow \mathrm{E}: \text { mental health } \\
\Uparrow \mathrm{C}: \text { mental health }\end{array}$ \\
\hline Singh et al. ${ }^{24}$ & 10 & $\begin{array}{c}E(20 \%): 69 \pm 5 \text { y }(n=17) \\
E(80 \%): 70 \pm 7 \text { y }(n=18) C: \\
69 \pm 7 \text { y }(n=19) \text { MD or minor } \\
\text { depression }\end{array}$ & $\begin{array}{l}\text { Longitudinal } \\
\text { ( } 8 \text { weeks) } \\
\text { supervised }\end{array}$ & $\begin{array}{c}\text { Strength } \\
3 \text { days/week } \\
3 \text { sets of } 8 \text { RM } \\
60 \text { minutes }\end{array}$ & SF-36 & $\begin{array}{l}\text { E > C: physical } \\
\text { function, role } \\
\text { physical, vitality, } \\
\text { social, emotional e } \\
\text { mental health }\end{array}$ \\
\hline Singh et al. ${ }^{23}$ & 10 & $\begin{array}{c}71.3 \pm 1.2 \\
E:(n=17) \\
C:(n=15) \text { MD, minor } \\
\text { depression or dysthymia }\end{array}$ & $\begin{array}{l}\text { Longitudinal } \\
\text { (10 weeks) } \\
\text { supervised }\end{array}$ & $\begin{array}{c}\text { Strength } \\
3 \text { days/week } 3 \text { sets } \\
\text { de } 8 \text { RM } 50 \text { minutes }\end{array}$ & SF-36 & $\begin{array}{c}\text { E > C: aspects pain } \\
\text { vitality, social and } \\
\text { emotional }\end{array}$ \\
\hline Steinberg et al..$^{25}$ & 6 & $\begin{array}{c}\text { E: } 76.5 \pm 3.9 \text { y }(n=14) \\
\text { C: } 74.0 \pm 8.1 \text { y }(n=13) \\
A D\end{array}$ & $\begin{array}{l}\text { Longitudinal } \\
\text { (12 weeks) } \\
\text { unsupervised }\end{array}$ & $\begin{array}{c}\text { Strength, balance, } \\
\text { aerobic and flexibility } \\
\text { Daily }\end{array}$ & $A D Q R L$ & $\begin{array}{l}\mathrm{E}: \Leftrightarrow \\
\mathrm{C}: \Leftrightarrow\end{array}$ \\
\hline Teri et al. ${ }^{26}$ & 6 & $\begin{array}{l}\text { E: } 78 \pm 6 \text { y } \\
(n=44) \\
C: 78 \pm 8 y \\
(n=45) \\
A D\end{array}$ & $\begin{array}{l}\text { Longitudinal } \\
\text { (24 months) } \\
\text { Unsupervised }\end{array}$ & $\begin{array}{c}\text { Strength, balance, } \\
\text { aerobic and flexibility } \\
2 \text { days / week } 30 \\
\text { minutes }\end{array}$ & SF-36 & $\begin{array}{l}\text { E > C: physical } \\
\text { function }\end{array}$ \\
\hline
\end{tabular}

$\mathrm{AD}=$ Alzheimer's disease; ADQRL = Alzheimer's Disease-Related Quality of Life; $\mathrm{C}=$ control; $\mathrm{E}=$ exercise; MD = major depression; SF-36 = Medical Outcomes Study 36-Item Short-Form Health Survey; PEDro = Physical Therapy Evidence Database.

Some experimental procedures of the studies included in this review should also be discussed. Lavretsky et al. ${ }^{21}$ investigated the role of physical exercises associated with meditation practices and compared results with those of a control group of individuals who participated in a health education program. Both the lack of a control group that received no interventions and the small size of the sample may have been limitations of this study. In another intervention study, Kerse et al. ${ }^{22}$ used a variety of non-supervised exercises and did not describe the method used to prescribe exercises. Therefore, it is not clear whether the type of control condition and the intensity of exercises might have played a role in the effect of exercise on QoL among elderly individuals with depression.

Although all studies included in this review were classified as high quality according to the evaluation of their methods, they had differences in their definition of clinical diagnoses of depression and type of exercises. One study included only individuals with major depression, ${ }^{21}$ but most investigated other types of depression, such as dysthymia and minor depression. ${ }^{22-24}$ Moreover, the use of drugs and the small size of the samples complicated the comparison of findings. Cognitive and functional aspects of $A D$ associated with the subjective evaluations of patients and caregivers may also affect QoL measures. ${ }^{34}$ The assessment of risk of bias revealed that different types of control groups, as well as the lack of blinding for allocations and follow-up evaluations, were important limitations of most studies. Future studies should include specific exercise prescriptions and QoL scales that assess cost-effectiveness, such as QALY and DALY.

\section{Conclusions}

Few studies met the inclusion criteria of this review, and no conclusion could be drawn about intensity and type of exercises to improve QoL of older individuals with depression. However, different types of exercise resulted in significant improvement of QoL among older individuals with depression, which suggests that physical exercise may be used as an additional non-pharmacological intervention in those cases. In addition, QoL assessments may be viewed as an outcome for physical exercise interventions in elderly individuals with depression or AD.

\section{Acknowledgements}

Helena Moraes (E-26/100.274/2013), Andrea Deslandes (E-26/102.174/2013), and Jerson Laks (E-26/112.631/2012) have received grants from Fundação de Amparo à Pesquisa do Rio de Janeiro (FAPERJ) and Conselho Nacional de Desenvolvimento Científico e Tecnológico (CNPq). 


\section{References}

1. Kinsella K, He W. An aging world: 2008. International Population Reports. Washington: U.S. Census Bureau; 2009. http://www. census.gov/prod/2009pubs/p95-09-1.pdf

2. Scazufca $M$, Cerqueira AT, Menezes $P R$, Prince $M$, Vallada $H P$, Miyazaki MC, et al. [Epidemiological research on dementia in developing countries]. Rev Saude Publica. 2002;36:773-8.

3. Chaimowicz $F$. A saúde dos idosos brasileiros às vésperas do século XXI: problemas, projeções e alternativas. Rev Saude Publica. 1997;31:184-200.

4. Fleck M, Chachamovich E, Trentini C. Development and validation of the Portuguese version if the WHOOOL-OLD module. Rev Saude Publica. 2006;40:785-91.

5. Coutinho ESF, Laks J. Saúde mental do idoso no Brasil: a relevância da pesquisa epidemiológica. Cad Saude Publica. 2012;28:412-3.

6. Blay SL, Andreoli SB, Fillenbaum GG, Gastal FL. Depression morbidity in later life: prevalence and correlates in a developing country. Am J Geriatr Psychiatry. 2007;15:790-9. Epub 2007 Aug 13.

7. Bowling A. Measuring disease. A review of disease-specific quality of life measurement scales. 2nd ed. Buckingham: Open University; 2001

8. Campolina AG, Bortoluzzo AB, Ferraz MB, Ciconelli RM. O questionário sf-6D Brasil: modelos de construção e aplicações em economia da saúde. Rev Assoc Med Bras. 2010;56:409-14.

9. Apeldoorn AT, Ostelo RW, van Helvoirt H, Fritz JM, de Vet HC, van Tulder MW. The cost-effectiveness of a treatment-based classification system for low back pain: design of a randomised controlled trial and economic evaluation. BMC Musculoskelet Disord. 2010;11:58.

10. Santana-Sosa E, Barriopedro MI, López-Mojares LM, Pérez M, Lucia A. Exercise training is beneficial for Alzheimer's patients. Int J Sports Med. 2008;29:845-50. Epub 2008 Apr 9.

11. Zhu CW, Sano M. Economic considerations in the management of Alzheimer's disease. Clin Interv Aging. 2006;1:143-54.

12. Sousa MF, Santos RL, Arcoverde C, Dourado M, Laks J. Consciência da doença na doença de Alzheimer: resultados preliminares de um estudo longitudinal. Rev Psiquiatr Clin. 2011;38:57-60.

13. Lima AF, Fleck M. Qualidade de vida e depressão: uma revisão de literatura. Rev Psiquiatr Rio Gd Sul. 2009;31:1-12.

14. Gusi N, Reyes MC, Gonzalez-Guerrero JL, Herrera E, Garcia JM. Cost-utility of a walking programme for moderately depressed, obese, or overweight elderly women in primary care: a randomised controlled trial. BMC Public Health. 2008;8:231.

15. Eyigor $S$, Karapolat $H$, Durmaz B. Effects of a group-based exercise program on the physical performance, muscle strength and quality of life in older women. Arch Gerontol Geriatr. 2007;45:259-71. Epub 2007 Feb 15.

16. Deslandes AC, Moraes $H$, Alves $H$, Pompeu FA, Silveira $H$, Mouta $R$, et al. Effect of aerobic training on EEG alpha asymmetry and depressive symptoms in the elderly: a 1 -year follow-up study. Braz J Med Biol Res. 2010;43:585-92. Epub 2010 May 14.

17. Spirduso WW, Cronin DL. Exercise dose-response effects on quality of life and independent living in older adults. Med Sci Sports Exerc. 2001;33(6 Suppl):S598-608.

18. Kerse N, Peri K, Robinson E, Wilkinson T, von Randow M, Kiata $L$, et al. Does a functional activity programme improve function, quality of life, and falls for residents in long term care? Cluster randomised controlled trial. BMJ. 2008;337:a1445.

19. Vaapio $S$, Salminen M, Vahlberg T, Sjösten N, Isoaho R, Aarnio $P$, et al. Effects of risk-based multifactorial fall prevention on health-related quality of life among the community-dwelling aged: a randomized controlled trial. Health Qual Life Outcomes. 2007;5:20.
20. Antunes HK, Stella SG, Santos RF, Bueno OF, de Mello MT. Depression, anxiety and quality of life scores in seniors after an endurance exercise program. Rev Bras Psiquiatr. 2005;27:26671. Epub 2005 Dec 12.

21. Lavretsky $H$, Alstein LL, Olmstead RE, Ercoli LM, Riparetti-Brown M, Cyr NS, et al. Complementary use of tai chi chih augments escitalopram treatment of geriatric depression: a randomized controlled trial. Am J Geriatr Psychiatry. 2011;19:839-50.

22. Kerse N, Hayman KJ, Moyes SA, Peri K, Robinson E, Dowell A, et al. Home-based activity program for older people with depressive symptoms: DeLLITE--a randomized controlled trial. Ann Fam Med. 2010;8:214-23.

23. Singh NA, Clements KM, Fiatarone MA. A randomized controlled trial of progressive resistance training in depressed elders. J Gerontol A Biol Sci Med Sci. 1997;52:M27-35.

24. Singh NA, Stavrinos TM, Scarbek $Y$, Galambos $G$, Liber C, Fiatarone Singh MA. A randomized controlled trial of high versus low intensity weight training versus general practitioner care for clinical depression in older adults. J Gerontol A Biol Sci Med Sci. 2005; 60:768-76.

25. Steinberg M, Leoutsakos JM, Podewils LJ, Lyketsos CG. Evaluation of a home-based exercise program in the treatment of Alzheimer's disease: the Maximizing Independence in Dementia (MIND) study. Int J Geriatr Psychiatry. 2009;24:680-5.

26. Teri L, Gibbons LE, McCurry SM, Logsdon RG, Buchner DM, Barlow $W E$, et al. Exercise plus behavioral management in patients with Alzheimer disease: a randomized controlled trial. JAMA. 2003;290:2015-22.

27. Schuch FB, Vasconcelos-Moreno MP, Fleck MP. The impact of exercise on quality of life within exercise and depression trials: a systematic review. Mental Health Phys Act. 2011;4:43-8.

28. Potter R, Ellard D, Rees K, Thorogood M. A systematic review of the effects of physical activity on physical functioning, quality of life and depression in older people with dementia. Int J Geriatr Psychiatry. 2011;26:1000-11. Epub 2011 Jan 6.

29. Shiwa SR, Costa LO, Moser AD, Aguiar IC, Oliveira LV. PEDro: a base de dados de evidências em fisioterapia. Fisioter Mov. 2011;24:523-33.

30. Ciconelli RM, Ferraz MB, Santos WS, Meinão I, Quaresma MR. Tradução para a língua portuguesa e validação do questionário genérico de avaliação de qualidade de vida SF-36 (Brasil SF-36). Rev Bras Reumatol. 1999;39:143-50.

31. Stella F, Gobbi S, Corazza DI, Costa JL. Depressão no idoso: diagnóstico, tratamento e benefícios da atividade física. Motriz. 2002;8:91-8.

32. Netuveli G, Blane D. Quality of life in older ages. Br Med Bull. 2008;85:113-26. Epub 2008 Feb 15.

33. Fleck MP, Chachamovich E, Trentini CM. [WHOQOL-OLD Project: method and focus group results in Brazil]. Rev Saude Publica. 2003;37:793-9. Epub 2003 Nov 27.

34. Rabins PV, Kasper JD, Kleinman L, Black B, Patrick DL. Concepts and methods in the development of the ADRQL: an instrument for assessing health-related quality of life in persons with Alzheimer's disease. J Ment Health Aging. 1999;5:33-48.

\section{Correspondence:}

Bianca Boscarino Tavares

Rua Trinta de Maio, 87, Penha

21020-240 - Rio de Janeiro, RJ - Brazil

Tel.: +55 (21) 9643.3144

E-mail: biancaboscarino@yahoo.com.br 